\title{
Nauczyciel wobec współczesnych zjawisk stresogennych w miejscu pracy - wielowymiarowość konsekwencii i przyczyn
}

\author{
The Teacher and Contemporary \\ Stressful Phenomena in the Workplace - \\ the Multidimensionality of \\ Consequences and Causes
}

\begin{abstract}
ABSTRAKT
Celem artykułu jest ukazanie charakterystyki zjawiska stresu zawodowego w zawodzie nauczyciela. Stres zawodowy jest zjawiskiem przybierajqcym na sile we współczesnym świecie wraz z dokonujqcymi się przemianami ekonomicznymi, demograficznymi czy też społecznymi. Zawód nauczyciela wpisuje się w pulę zawodów charakteryzujqcych się bardzo dużym ryzykiem występowania stresu w jego obrębie, $z$ racji konieczności podejmowania $w$ nim pracy $z$ drugim człowiekiem. Wszystkie czynniki stresogenne, z którymi styka się nauczyciel w szkole, maja wpływ na jego funkcjonowanie, kondycje psychicznq i fizycznq, a w rezultacie rzutuja na jakość współczesnego kształcenia. Dlatego w rozważaniach podjęto tematykę stresu zawodowego nauczycieli jako problemu aktualnego i przybierajqcego na sile, ze szczególnym uwzględnieniem zjawisk stresogennych,
\end{abstract}

SLOWA KLUCZOWE stres zawodowy, nauczyciel, zjawiska stresogenne, wypalenie zawodowe, czynniki wspierajace

\section{KEYWORDS}

occupational stress, teacher, stressful phenomena, burnout syndrome, support factors

SPI Vol. 22, 2019/1

ISSN 2450-5358

e-ISSN 2450-5366

DOI: 10.12775/SPI.2019.1.005

Nadesłano: 27.09 .2018 Zaakceptowano: 18.03.2019

Artykuły i rozprawy 
jakie występuja w miejscu zatrudnienia głównego bohatera artykułu, i przyczyn ich występowania. Dokonany przeglad literatury naukowej oraz raportów z badań z tego obszaru pozwolił na pokazanie szeregu konsekwencji, jakie niesie za sobq obciqżenie stresem w tej grupie zawodowej, nie tylko dla samej osoby nauczyciela, ale też jego rodziny, najbliższych, ucznia, z kłórym pracuje, jak i funkcjonowania placówki, w której jest zatrudniony.

\section{ABSTRACT}

The aim of the article is to show the characteristics of the phenomenon of professional stress in the teaching profession. Professional stress is a phenomenon that is gaining momentum in the modern world, along with economic, demographic or social changes. The profession of a teacher is part of a pool of professions characterized by a very high risk of stress within it, due to the necessity of working with other people. All the stressful factors that a teacher encounters at school undoubtedly affect their functioning, mental and physical condition and, as a result, the quality of modern education. Therefore, in the considerations I will deal with the subject of teachers' professional stress as a still-present and growing problem, with particular emphasis on the stressful phenomena that occur in the place of employment of the main character of the article and the reasons for their occurrence. The review of the scientific literature and research reports from this area aided the illustration of a number of consequences that the stress burden in this professional group entails, not only for the teachers themselves, but also their family, relatives, the students with whom they work, and the functioning of the institution in which they are employed.

\section{Zjawisko stresu zawodowego w pracy nauczyciela}

Aktywność na polu zawodowym bez wątpienia stanowi główny element funkcjonowania społecznego, biorąc pod uwagę inne aktywności funkcjonowania człowieka. Dzisiejszy świat nacechowany jest sytuacjami, w których praca zawodowa staje się punktem zapalnym dla różnorakich kryzysów dotykających zarówno sferę prywatną, jak i zawodową osób ich doświadczających.

Środowiska pedagogiczne to miejsca, gdzie zjawisko stresu zawodowego wciąż przybiera na sile, a liczne przeobrażenia ekonomiczne, 
społeczne i zawodowe poszerzają jego obraz o coraz to nowsze obszary. Stres w miejscu pracy nie dotyka tylko i wyłącznie osób z bogatym stażem zawodowym. Badacze zjawiska wypalenia zawodowego zwracają coraz częściej uwagę na zjawisko tzw. szoku zawodowego, tj. stresu pojawiającego się już w momencie rozpoczęcia działalności zawodowej, jako konsekwencji rozbieżności pomiędzy wyobrażeniami o zatrudnieniu a warunkami rzeczywistymi, z jakimi styka się pracownik $^{1}$. Należy podkreślić, że szereg negatywnych konsekwencji, zarówno dla pracownika, jak i dla placówki, która go zatrudnia, niesie sytuacja, gdy praca wywiera ujemny wpływ na zasoby osobiste pracowników.

Możemy pokusić się o stwierdzenie, że nie ma zawodów nie obarczonych czynnikami ryzyka, które przy niedoborze zasobów osobistych mogą uaktywniać w człowieku proces wypalania się. Istnieje jednak pula zawodów szczególnie narażonych na stres, a w ich poczet bez wątpienia możemy zaliczyć zawód nauczyciela.

Początki badań nad stresem w tym zawodzie sięgają już lat siedemdziesiątych XX wieku, kiedy to poddani badaniom czynni zawodowo nauczyciele w 1/3 zadeklarowali, że w swojej pracy przeżywają szereg stresów związanych z jej wykonywaniem² ${ }^{2}$.

\section{Czynniki stresogenne w edukacji}

W 2007 roku Jacek Pyżalski i Piotr Plichta przeprowadzili badania, w których za pomocą różnych skal starali się zdiagnozować najbardziej uciążliwe elementy związane z pracą pedagogiczną oraz ich rozkład w całej populacji. Przekrojowym narzędziem wykorzystanym w tym badaniu była skala: Obciążenia Organizacyjne. Kwestionariusz Obciążeń Pedagoga. Narzędzie to pokazuje, w jakim stopniu badani nauczyciele odbierają określone sfery swojego środowiska. Zebrany materiał pokazał, że nauczycielom najbardziej przeszkadza fakt, że zarabiają niewspółmiernie mało do nakładu swojej pracy.

1 Por. K. Krasoń, Ksztatcenie nauczycieli - pytania niechciane czy konieczne? Reinterpretacja kompetencji pedagogicznych na przyktadzie poziomu edukacji wczesnoszkolnej, w: Edukacja jutra. Wyzwania wspótczesności i przyszłości, red. A. Kamińska, W. Łuszczuk, P. Oleśniewicz, Sosnowiec 2012, s. 170.

2 Por. Z. Marten, Stres w pracy nauczyciela, 2007, s. 99. 
$\mathrm{Na}$ kolejnych miejscach znalazły się takie pozycje, jak m.in. przeładowane plany i programy nauczania, zbyt duża liczba uczniów, brak wsparcia ze strony zarówno współpracowników, jak i przełożonego, ale również nieodpowiednie warunki lokalowe, w jakich przychodzi im pracować. Nauczyciele podkreślali również, że dotyka ich fakt, iż nie mają zbyt dużego wpływu na pracę szkoły, a istotne decyzje podejmowane w placówce nie są z nimi konsultowane ${ }^{3}$.W dalszej części artykułu postaram się szerzej omówić wybrane czynniki stresogenne w pracy zawodowej nauczyciela, które rzutują na jego samopoczucie zarówno w miejscu pracy, jak i poza nią.

Należy zwrócić uwagę na to, że za najbardziej obciążające aspekty nauczyciele uważają elementy ich pracy związane z organizacją systemu oświaty. Jak podaje raport „Education at a Glance” z 2017 roku, zarobki polskich nauczycieli są wciąż najniższe w krajach Organizacji Współpracy Gospodarczej i Rozwoju. Listę niskich płac zamykamy wraz z Czechami, Słowacją i Węgrami. Co więcej, średnie wynagrodzenie nauczycieli w Polsce jest niższe od średniego wynagrodzenia osób z wyższym wykształceniem ${ }^{4}$.

Ograniczona autonomia nauczycieli $\mathrm{w}$ miejscach zatrudnienia jest kolejnym problem, z którym muszą mierzyć się polscy nauczyciele. Szkolnictwo publiczne jako część sfery budżetowej jest ufundowane na dużej liczbie regulacji prawnych, które nałożone są zarówno na szkołę, jak i na nauczyciela. Częste zmiany dokonywane w ramach reform edukacji są również elementem zapalnym stresu zawodowego w tej grupie. Doskonałym przykładem są tutaj badania prowadzone w latach dwudziestych XX wieku w Teksasie, kiedy wchodziła tam w życie reforma edukacji związana $z$ tworzeniem standardów pracy nauczyciela oraz zewnętrzną oceną wyników jego pracy. Prowadzone

3 J. Pyżalski, P. Plichta, Kwestionariusz Obciażen Zawodowych Pedagoga (KOZP). Podręcznik, Łódź 2007; J. Pyżalski, Stresory w środowisku pracy nauczyciela, w: Psychospoteczne warunki pracy polskich nauczycieli. Pomiędzy wypaleniem zawodowym a zaangażowaniem, red. J. Pyżalski, D. Merecz, Kraków 2010, s. 53.

4 Por. https://www.oecd-ilibrary.org/education/education-at-a-glance-2017_ eag-2017-en [dostęp: 12.09.2018]. 
na polu politycznym działania przełożyły się na odnotowanie w tej grupie zawodowej dużego poczucia niepewności oraz niestabilności ${ }^{5}$.

$\mathrm{W}$ wielu krajach prawodawstwo wiąże się z kurczeniem się autonomii nauczyciela, chociażby w kwestii indywidulanego wyboru co do form, treści czy metod nauczania. Ma to związek z odgórnym unifikowaniem edukacyjnych rozwiązań oraz zewnętrznej oceny wyników kształcenia. Innym aspektem, który należy podkreślić, a na który zwracają szczególną uwagę nauczyciele, jest formalny system kształcenia, niewłaściwie przygotowujący do podjęcia pracy w tym zawodzie. Nauczyciele podkreślają, że nie są przygotowani do podstawowych czynności w pracy z uczniem, chociażby takich, jak utrzymanie dyscypliny, kontakt $\mathrm{z}$ rodzicem, dostosowanie metod, form i treści pracy do konkretnego ucznia ${ }^{6}$.

Niewłaściwe relacje w gronie pedagogicznym i brak wsparcia ze strony dyrekcji to kolejne aspekty, na które zwrócili uwagę nauczyciele w raporcie obciążeń zawodowych. Jak pokazują badania, wydajność pracownika $\mathrm{w}$ miejscu zatrudnienia ma ścisły związek $\mathrm{z}$ tym, jakie posiada on relacje ze swoimi współpracownikami, jak również z przełożonym ${ }^{7}$.

$\mathrm{Na}$ problem kształtowania się relacji w gronie pedagogicznym zwróciła uwagę Joanna M. Łukasik, badając życie codzienne nauczycieli. W wyniku zainicjowanego przez siebie konkursu „Miesiąc z życia nauczyciela”, listów do redakcji „Gazety Szkolnej”, analizy wypowiedzi na blogach oraz komentarzy zamieszczanych w Internecie zauważyła, że młodzi nauczyciele z krótkim stażem zawodowym są bardzo często narażeni na nieprzychylność ze strony starszych kolegów. Rodzi to problem w budowaniu z nimi pozytywnej relacji. Taki stan rzeczy spowodowany jest $z$ dużym prawdopodobieństwem obroną swojej pozycji zawodowej, zbudowanej przez nich przez lata. Dialog zastępuje przymus i autorytarne nakazy. Często obciążają oni

5 Por. V. Brenninkmeijer, N. van Yperen, B. Buunk, I am not a better teacher, but others are doing worse: Burnout and perceptions of superiority among teachers, „Social Psychology of Education” 2001, nr 4, cyt. za: J. Pyżalski, Stresory w środowisku pracy nauczyciela, dz. cyt., s. 54.

6 Por. J. Prucha, Pedeutologia, w: Pedagogika, red. B. Śliwerski, t. 2: Pedagogika wobec edukacji, polityki oświatowej i badań naukowych, Gdańsk 2006, s. 293-316.

7 Por. E. Masłyk-Musiał, Spoteczeństwo i organizacje, Lublin 1999, s. 82. 
młodszych kolegów nadprogramowymi zadaniami, jak sporządzanie protokołów z rad pedagogicznych, dodatkowe dyżury, sprawdzanie wypracowań, argumentując swoje zachowanie większym stażem zawodowym. Sytuacja taka na dłuższą metę prowadzi do osłabienia motywacji do pracy u młodych pracowników, braku zaufania i wspólnoty wśród grona pedagogicznego, a w konsekwencji niepodejmowania wspólnych działań na linii zawodowej.

Raport z Międzynarodowego Badania Nauczania i Uczenia się z 2013 roku pokazuje, że relacje w gronie pedagogicznym w polskich szkołach niekoniecznie kształtują się tak, jak powinny. Wprawdzie 93\% dyrektorów szkół deklaruje, że ich pracownicy otwarcie i swobodnie omawiają problemy, jakie spotykają na swojej drodze zawodowej, dążąc do wypracowania wspólnych rozwiązań, ale tylko 18\% wybiera odpowiedź „zdecydowanie tak” w ankiecie. W porównaniu z innymi krajami, np. Słowacją, daje to różnicę 23\%. Raport pokazuje również, że w Polsce istnieją duże rozbieżności co do stopnia nasilenia wykorzystywania różnorakich form współpracy nauczycieli, takich jak np. wymiana materiałów dydaktycznych pomiędzy nauczycielami, obserwacja lekcji prowadzonych przez swoich kolegów czy uczestnictwo w grupowych działaniach, mających na celu doskonalenie warsztatu9.

Rozpatrując czynniki stresogenne w pracy nauczyciela z perspektywy jego relacji z przełożonym i pracownikami, warto wspomnieć również, co pokazują światowe analizy, że pracownicy sektora edukacji to grupa zawodowa szczególnie narażona na zjawisko mobbingu w miejscu pracy. Częstotliwość tego zjawiska została zbadana również w Polsce. Badania pokazały, że prawie $10 \%$ badanych nauczycieli (z grupy 1098 poddanych badaniu) styka się z wrogimi zachowaniami ze strony przełożonego w miejscu swojego zatrudnienia. Wymieniają oni takie zachowania, jak m.in. zlecanie dodatkowych zadań, pracę poniżej kompetencji, niewiedzę ze strony przełożonego w stosunku do ich przekonań i poglądów ${ }^{10}$.

8 Por. J.M. Łukasik, Komunikacja a relacje w gronie nauczycieli. O rzeczywistości wykorzenionej z ideatu, „Debata Edukacyjna”2011, nr 4, s. 54-58.

9 Por. Polscy nauczyciele i dyrektorzy w Międzynarodowym Badaniu Nauczania i Uczenia się TALIS 2013, Warszawa 2015, s. 50-63.

10 Por. M. Warszewska-Makuch, Zjawisko mobbingu wśród nauczycieli, „Bezpieczeństwo Pracy" 2008, nr 5, s. 6-9. 
Przeciążenie pracą stanowi istotny czynnik stresogenny, co potwierdzają zarówno polskie, jak i światowe badania, chociażby prowadzone w Finlandii czy Australii. Fińscy nauczyciele przypisują wysoką pozycję dużej liczbie obowiązków w hierarchii obciążeń, z jakimi styka się nauczyciel ${ }^{11}$. Z kolei na antypodach nauczyciele wskazywali, że nie radzą sobie z ilością obowiązków zarówno czasowo, jak i ilościowo ${ }^{12}$.

Polscy nauczyciele wskazali na problem rosnących partii materiału dydaktycznego, który w wyniku ograniczeń czasowych bardzo często zostaje niezrealizowany, jak również fakt, że stosunkowo dużo czasu zajmuje im przygotowywanie się do zajęć dydaktycznych. Szczególny głos w tej kwestii należał do kobiet, które w wyniku nadmiernych obciążeń zderzały się niejednokrotnie $\mathrm{z}$ konfliktem ról na linii praca - dom, mając poczucie niekompletnego wywiązywania się $\mathrm{z}$ ról nie tylko zawodowych, ale i osobistych ${ }^{13}$.

Wydawać by się mogło, że wciąż podlegający transformacjom rynek pracy wychodzi naprzeciw problemom i troskom współczesnego pracownika. Wrażenie to jest jednak złudne, a możliwość bezkonfliktowego godzenia ról rodzinnych i zawodowych staje się wciąż odległą perspektywą ${ }^{14}$.

Badania pokazują, że nauczycielka, która jest jednocześnie żoną lub matką, zawsze ponosi szereg kosztów psychologicznych, rzutujących zarówno na jej sferę rodzinną, jak i zawodową ${ }^{15}$. Oprócz wyczerpania fizycznego i psychicznego, osłabiają się jej kontakty społeczne, odczuwa wyrzuty sumienia $\mathrm{z}$ powodu niepełnego wywiązywania się

11 N. Santavirta, S. Solovieva, S. Theorell, The association between job strain and emotional exhaustion in a cohort of 1,028 Finnish teachers, „British Journal of Educational Psychology" 2007, t. 77, nr 1, cyt. za: J. Pyżalski, Skutki oddziatywania warunków pracy na polskich nauczycieli, w: Psychospoteczne warunki pracy polskich nauczycieli, dz. cyt., s. 31.

12 Por. Australian Council for Educational Research, Report on secondary teacher workload study, 2004, http://www.educationcounts.govt.nz/publications/ schooling/ 11853 [dostęp: 12.07.2018].

13 Por. F. Adamski, Rodzina. Wymiar spoteczno-kulturowy, Kraków 2002, s. 207.

14 Por. E. Mandal, Kobiecość i meskość. Popularne opinie a badania naukowe, Warszawa 2003, s. 38.

15 Por. I. Chmura-Rutkowska, Getto nauczycielek - w putapce stereotypu, w: Pteć i rodzaj w edukacji, red. M. Chomczyńska-Rubacha, Łódź 2004, s. 115. 
z powierzonych jej ról, pojawia się aspekt lojalności w kontekście realizacji powierzonych zobowiązań ${ }^{16}$.

Kobieta nauczycielka, godząca etat zawodowy z obowiązkami domowymi, bardzo często styka się również z brakiem wsparcia ze strony partnera, czyli zostaje zubożona o element wsparcia społecznego, tak istotny w profilaktyce wypalenia zawodowego, a - jak donoszą badania - ich zaangażowanie czasowe w obowiązki domowe jest trzykrotnie wyższe od zaangażowania mężczyzn ${ }^{17}$.

Głównym elementem pracy nauczyciela pozostaje jednak kontakt z uczniem. Nie ulega wątpliwości, że to, jak zachowują się uczniowie, wpływa na kondycję psychiczną osoby uczącej. To, jak stres negatywnie wpływa na postawę nauczyciela, w ciekawy sposób pokazały badania prowadzone na gruncie polskim, które badały częstotliwość występowania reakcji u nauczycieli związanych z pojawieniem się negatywnych zachowań ze strony ucznia na kanwie ich cech socjodemograficznych. Badanie zakładało również analizę, które $z$ omawianych cech stanowią element obronny w procesie wypalania się. Próba licząca ponad 400 nauczycieli, których średni staż pracy wyniósł 14 lat, z pominięciem nauczycieli stażystów ze względu na małe doświadczenie zawodowe, poddana dwutygodniowym analizom pokazała, że nauczyciele w pierwszej kolejności stykają się z tą grupą zachowań uczniów, które mają mniejszą rangę, ale dużą częstotliwość. Są to takie zachowania, jak: spóźnianie się na lekcje, oszukiwanie podczas testów sprawdzających poziom wiedzy, hałasowanie podczas zajęć lekcyjnych i przerw, przerywanie wypowiedzi nauczyciela podczas zajęć.

Zachowania o poważniejszym charakterze (agresja słowna i fizyczna, używanie wulgaryzmów) podczas trwania obserwacji miały miejsce stosunkowo rzadko. Jednak badacze podkreślają, że czas badania był na tyle krótki, że nie daje on podstaw do pominięcia tych czynników i zakwalifikowania ich jako nieistotnych w rozwoju stresu zawodowego u nauczycieli. W efekcie nauczyciele, którzy wskazywali na stosunkowo częste pojawianie się niewłaściwych postaw ze strony swoich uczniów, uzyskiwali wyższe wyniki na skalach wypalenia zawodowego. Ciekawym pozostaje również fakt, że zdecydowanie

16 Por. F.R. Elliot, The family: Change or continuity?, Basingstoke-London 1986, s. 68.

17 Por. I. Chmura-Rutkowska, Getto nauczycielek - w putapce stereotypu, dz. cyt., s. $116-118$. 
częściej z niewłaściwymi zachowaniami ze strony uczniów musieli mierzyć się nauczyciele, nie nauczycielki ${ }^{18}$.

W zawód nauczyciela wpisana jest również konieczność kontaktu z rodzicami uczniów. Jak pokazują badania dla nauczycieli, fakt ten stanowi pewnego rodzaju niedogodność, która często jest powodem doświadczania przez nich dodatkowego stresu w miejscu pracy. Jak sami podkreślają, starają się traktować konieczność kontaktu z rodzicem jako tylko i wyłącznie swój obowiązek ${ }^{19}$.

Relacje rodzic-nauczyciel bardzo często cechuje wrogość, brak zaufania, niepewność. Brak w nich partnerstwa i świadomości, że kontakt pomiędzy nimi ma służyć wspólnemu celowi - dobru ucznia. Nauczyciele skarżą się na roszczeniową postawę rodziców wobec nich, równocześnie wytykając im bierność i stagnację, jeżeli chodzi o angażowanie się w sprawy szkolne. Jako przykład podają chociażby małą aktywność podczas zebrań, niechęć do angażowania się w sprawy klasowe, jak np. przynależność do klasowej trójki ${ }^{20}$.

Inne badania pokazały, że istnieje spory odsetek nauczycieli deklarujących, że spotkania $\mathrm{z}$ rodzicami wiążą się dla nich ze stanem psychicznego wyczerpania. Wskazywali oni również na problem braku wsparcia ze strony rodziców w kontekście pracy wychowawczej $\mathrm{z}$ dzieckiem oraz przerzucania na nich winy za brak sukcesów dziecka w szkole ${ }^{21}$.

\section{Podsumowanie}

Jak pokazują powyższe przykłady, nauczyciel na co dzień musi mierzyć się z szeregiem czynników stresogennych w swojej pracy zawodowej. Tylko i wyłącznie od jego zasobów indywidualnych

18 Por. M.L. Lanza, Nurses as patient assault victims: An update, synthesis and recommendations, „Archives of Psychiatric Nursing” 1992, nr 6, cyt. za: M. Drabek, D. Merecz, A. Mościcka, Mobbing w środowisku pracy. Charakterystyka zjawiska, jego konsekwencje, aspekty prawne i sposoby przeciwdziatania, Eódź 2005, s. 11.

19 Por. W. Żłobicki, Rodzice i nauczyciele w edukacji wczesnoszkolnej, Kraków 2000; M. Babiuch, Jak pracować z rodzicami „trudnych” uczniów?, Warszawa 2002, s. 12 .

20 Por. tamże.

21 Por. J. Pyżalski, Stresory w środowisku pracy nauczyciela, dz. cyt., s. 69. 
i wsparcia środowiskowego będzie zależało to, w jakim stopniu uchroni się on przed ich negatywnymi skutkami. Zarówno dyrekcja, jak i osoby jej podległe powinny pamiętać o tym, że wzajemna życzliwość, szacunek dla siebie, wsparcie w codziennych zawodowych problemach, są pierwszym systemem zaradczym przed negatywnymi konsekwencjami stresu w miejscu zatrudnienia. Nauczyciel aktywny zawodowo powinien również wypracować sobie sieć wsparcia wśród osób nie związanych z nim zawodowo. Kluczem do zminimalizowania negatywnych czynników wywołujących wypalenie się pracą zawodową jest pomoc i wsparcie najbliższych.

\section{Bibliografia}

Adamski F., Rodzina. Wymiar spoteczno-kulturowy, Wydawnictwo Uniwersytetu Jagiellońskiego, Kraków 2002.

Australian Council for Educational Research, Report on secondary teacher workload study, 2004, http://www.educationcounts.govt.nz/publications/ schooling/ 11853 [dostęp: 12.07.2018].

Babiuch M., Jak pracować z rodzicami „trudnych” uczniów?, Wydawnictwa Szkolne i Pedagogiczne, Warszawa 2002.

Brenninkmeijer V., van Yperen N., Buunk B., I am not a better teacher, but others are doing worse: Burnout and perceptions of superiority among teachers, „Social Psychology of Education” 2001, nr 4, s. 259-274.

Chmura-Rutkowska I., Getto nauczycielek - w putapce stereotypu, w: Pteć i rodzaj w edukacji, red. M. Chomczyńska-Rubacha, WSHE, Łódź 2004, s. $109-121$.

Drabek M., Merecz D., Mościcka A., Mobbing w środowisku pracy. Charakterystyka zjawiska, jego konsekwencje, aspekty prawne i sposoby przeciwdziatania, Instytut Medycyny Pracy im. Prof. J. Nofera, Łódź 2005.

https://www.oecd-ilibrary.org/education/education-at-a-glance-2017_eag2017-en [dostęp: 12.09.2018].

Lanza M.L., Nurses as patient assault victims: An update, synthesis and recommendations. „Archives of Psychiatric Nursing” 1992, nr 6 (3), s. 163-171.

Elliot F.R, The family: Change or continuity?, MacMillan Press, Basingstoke-London 1986.

Krasoń K., Ksztatcenie nauczycieli - pytania niechciane czy konieczne? Reinterpretacja kompetencji pedagogicznych na przyktadzie poziomu edukacji wczesnoszkolnej, w: Edukacja jutra. Wyzwania wspótczesności i przysztości, red. A. Kamińska, W. Łuszczuk, P. Oleśniewicz, Oficyna Wydawnicza Humanitas, Sosnowiec 2012, s. 161-181.

Łukasik J.M., Komunikacja a relacje w gronie nauczycieli. O rzeczywistości wykorzenionej z ideatu, „Debata Edukacyjna” 2011, nr 4, s. 54-59. 
Mandal E., Kobiecośc i męskość. Popularne opinie a badania naukowe, Wydawnictwo Akademickie „Żak”, Warszawa 2003.

Marten Z., Stres w pracy nauczyciela, Oficyna Wydawnicza Humanitas, Sosnowiec 2007.

Masłyk-Musiał E., Spoteczensstwo i organizacje, Wydawnictwo Uniwersytetu Marii Curie- Skłodowskiej, Lublin 1999.

Polscy nauczyciele $i$ dyrektorzy w Międzynarodowym Badaniu Nauczania i Uczenia sie TALIS 2013, Instytut Badań Edukacyjnych, Warszawa 2015.

Prucha J., Pedeutologia, w: Pedagogika, red. B. Śliwerski, t. 2: Pedagogika wobec edukacji, polityki oświatowej i badań naukowych, GWP, Gdańsk 2006, s. 293-316.

Pyżalski J., Skutki oddziatywania warunków pracy na polskich nauczycieli, w: Psychospoteczne warunki pracy polskich nauczycieli. Pomiędzy wypaleniem zawodowym a zaangażowaniem, red. J. Pyżalski, D. Merecz, Oficyna Wydawnicza „Impuls”, Kraków 2010, s. 31-47.

Pyżalski J., Stresory w środowisku pracy nauczyciela, w: Psychospoteczne warunki pracy polskich nauczycieli. Pomiędzy wypaleniem zawodowym a zaangażowaniem, red. J. Pyżalski, D. Merecz, Oficyna Wydawnicza „Impuls”, Kraków 2010, s. 53-75.

Pyżalski J., Plichta P., Kwestionariusz Obciqżeń Zawodowych Pedagoga (KOZP). Podręcznik, Wydawnictwo Uniwersytetu Łódzkiego, Łódź 2007.

Santavirta N., Solovieva S., Theorell S., The association between job strain and emotional exhaustion in a cohort of 1,028 Finnish teachers, „British Journal of Educational Psychology" 2007, t. 77, z. 1, s. 213-228.

Warszewska-Makuch M., Zjawisko mobbingu wśród nauczycieli, „Bezpieczeństwo Pracy" 2008, nr 5, s. 6-9.

Żłobicki W., Rodzice i nauczyciele w edukacji wczesnoszkolnej, Oficyna Wydawnicza Impuls, Kraków 2000.

\section{ADRES DO KORESPONDENCJ}

Mgr Anna Malisz

Akademia Ignatianum w Krakowie

Wydział Pedagogiczny

Instytut Nauk o Wychowaniu

e-mail: aniam170@gmail.com 